\title{
Domiciliation Trend of Panstrongylus rufotuberculatus in Colombia
}

\author{
Marta Wolff, Diana Castillo
}

Grupo Interdisciplinario de Estudios Moleculares, University of Antioquia, AA 1226, Medellín, Colombia

The present paper presents evidence of the domiciliation of Panstrongylus rufotuberculatus in La Gardenia, Colombia through the collection of 2 unhatched eggs, 81 nymphs and 10 adults (4 males and 6 females), from 2 rural houses. The transmission risk indicators of Trypanosoma cruzi by P. rufotuberculatus in La Gardenia, were: domiciliary infestation $7.5 \%$, density 2.35 , colonization $66.6 \%$, overcrowding 31.33 , natural infection $4.6 \%$, and relative infection $2.5 \%$.

These results and findings in Peru and Argentina, show that P. rufotuberculatus has a potential success in domiciliation and could some day become an alternate vector of American trypanosomiasis.

Key words: Triatominae - domiciliation - Panstrongylus rufotuberculatus - Colombia

Panstrongylus rufotuberculatus (Hemiptera, Reduviidae, Triatominae) has a wide distribution in Mexico, Costa Rica, Panama, Colombia, Venezuela, Ecuador, Peru, Bolivia, Brazil and Argentina (Lent \& Jurberg 1969, Lent \& Wygodzinsky 1979, Schofield 1994, Salomon et al. 1999).

Though frequently attracted to human dwellings by electric light (Lent \& Wygodzinsky 1979, Salomon et al. 1999), P. rufotuberculatus has been found in refuges of sylvatic animals, such as kinkajous (Potos flavus), vampire bats (Desmodus rotundus), armadillos and opossums (Lent \& Wygodzinsky 1979, D’ Alessandro et al. 1981, Miles et al. 1981), being frequently found naturally infected with Trypanosoma cruzi (Lent \& Pifano 1940, Lent \& Wygodzinsky 1979, Dujardin et al. 1998). Domestic colonies of $P$. geniculatus have also been reported from Peru (Calderón et al. 1985) and Bolivia (Dujardin et al. 1998).

Of the 23 species of Triatominae found in Colombia (Molina et al. 2000), P. rufotuberculatus has been reported in Antioquia (Moreno 1991), Boyacá (Pinto et al. 1999), Cauca (D' Alessandro et al. 1981, Barreto et al. 1988), Cundinamarca (Molina et al. 2000), Meta (Marinkelle 1972), Santander (Angulo et al. 1999) and, between 650 and 1100 $\mathrm{m}$ above sea level, in Valle del Cauca, humid tropical forest of the Pacific (D' Alessandro et al. 1981, Barreto \& Barreto 1984, Barreto et al. 1988).

In order to study the ecoepidemiology of Chagas disease in the northeast of Antioquia, Colombia, we determined the domiciliation and situation of potential vectors of $T$. cruzi in a rural coffee growing area considered not endemic. The constant complaints of the rural inhabitants bitten by an unknown insect was the principal motivation of this research.

This investigation received financial support from the UNDP/ World Bank/WHO Special Programme for Research and Training in Tropical Diseases (TDR), project T80/181/180 ID no. 990396, and from the University of Antioquia.

${ }^{+}$Corresponding author. Fax: +57-4-2330120. E-mail: mwolff@matematicas.udea.edu.co

Received 12 June 2001

Accepted 5 December 2001

\section{MATERIALS AND METHODS}

Area of study - The study was carried out in the locality of La Gardenia, $1,500 \mathrm{~m}$ asl, located in the municipality of Amalfi, northeast of the Department of Antioquia, Colombia (Lat N 6 55 '58" and Long W $75^{\circ} 05^{\prime} 30^{\prime \prime}$ ). The region is considered a transition zone between the tropical rain forest and the pre-montane humid forest. It has an average temperature of 18 to $24^{\circ} \mathrm{C}$ and annual rains ranging from 1,000 to 2,000 mm (Espinal 1985) (Fig. 1). The locality of La Gardenia lacks electric light and consists of 40 dwellings situated in a forest environment where the main activities are agriculture and hunting.

Sampling - The sampling of insects was performed in 40 houses, in order to determine risk indicators, according to the Indicator Definition Workshop for the Triatoma infestans Elimination Certification (OPS 1993). Having this as an aim, the search for triatomines was undertaken in the intra, peri and extra-domicile. In the intradomicile: in beds, cracks and wall interstices, on ground floors, under wooden floors and in clothes boxes and other household goods. In the peridomicile (around the dwelling, up to 10 $m$ away from it): mainly in resting places of wild animals (rodents and fowl) and domestic ones (dogs, chickens, hogs), and in the extra-domicile (around the dwelling, more than $10 \mathrm{~m}$ away from it), in abandoned or inhabited places of refuge of wild vertebrates of the zone, such as Didelphis mar-supialis, Proechimys sp., Philander opossum, Oryzomus sp., Hoplomys gymnurus, Marmosa robinsoni and Dasypus novemcinctus (Arboleda et al. 2000) and in trunks of trees, axillae of palm trees, fowl nests; in order to achieve this abandoned nests and samples of soil from refuges were taken to the laboratory. The material was revised under a stereomicroscope in search of some evidence indicating the presence of triatomines.

Taxonomic determination of collected bugs followed Lent and Wygodzinsky (1979); immature forms were reared to adult and the eggs were examined by scanning electron microscope to compare the external chorionic ornamentation of field collected and laboratory reared eggs of $P$. geniculatus (Figs 2, 3).

Detection of natural infection by T. cruzi - The live triatomines were evaluated using the spontaneous ejec- 


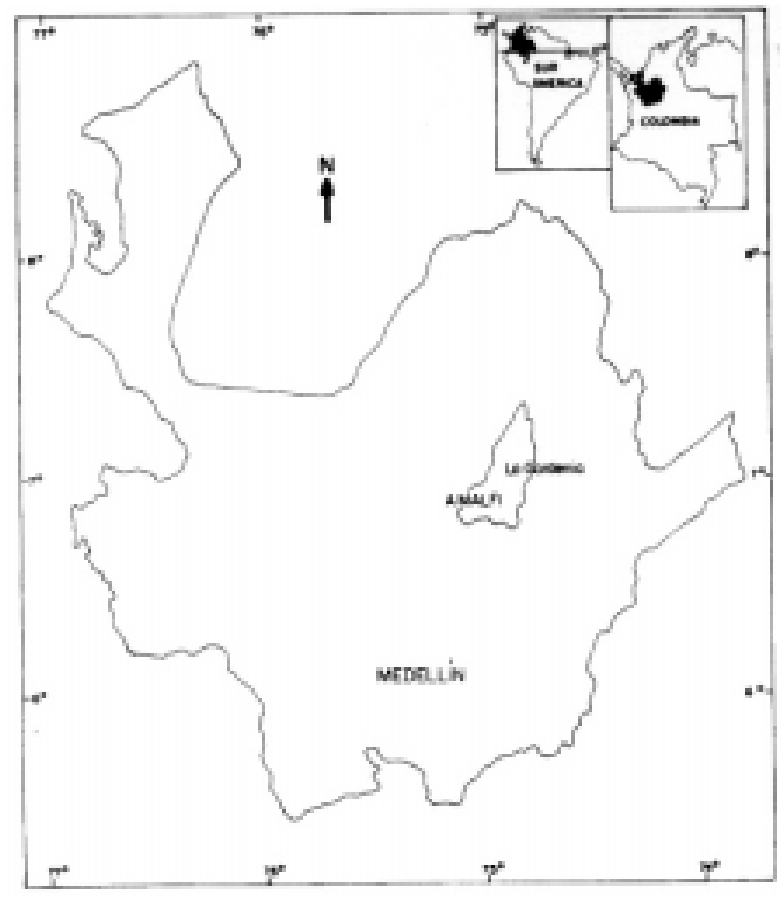

Fig. 1: study area. La Gardenia, Antioquia, Colombia, where Panstrongylus rufotuberculatus was found reproducing in intradomicile.

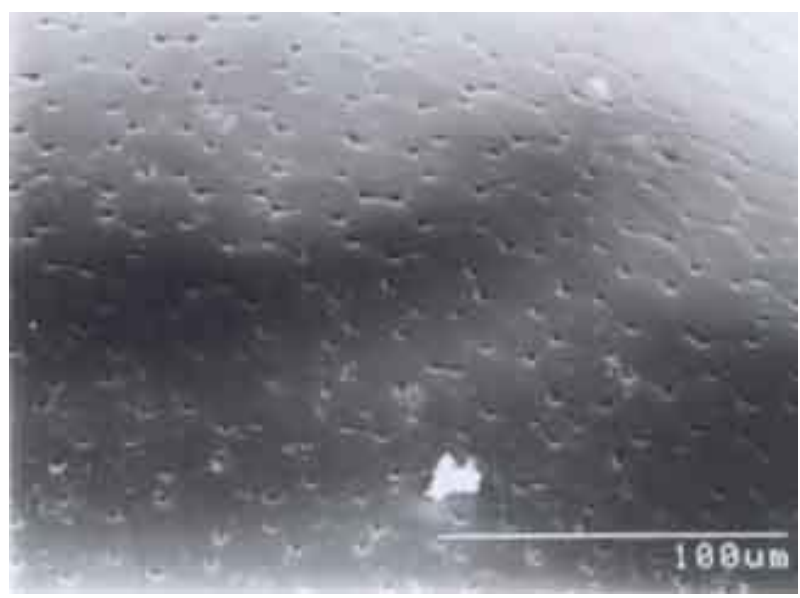

Fig. 2: scanning electron microscopy $(500 \mathrm{x})$. Details of the external cover of egg of Panstrongylus rufotuberculatus from indoors, in La Gardenia, Antioquia, Colombia.

tion technique (García Da Silva et al. 1993); they were submitted to feces revision, in order to evaluate positivity for Trypanosoma, upon arrival in the laboratory, after 30 and 45 days.

Triatominae dying during transportation to the laboratory or those collected dead were evaluated by aspiration of the intestine. This was done by injecting the insect's abdomen with $0.1 \mathrm{ml}$ of PBS using a tuberculin syringe, and then aspiring the intestinal content.

In both cases, feces were diluted in sterile PBS ( $\mathrm{pH}$ 7.2) and colored with Giemsa (Carvajal et al. 1995) to determine by morphology the species of Trypanosoma.

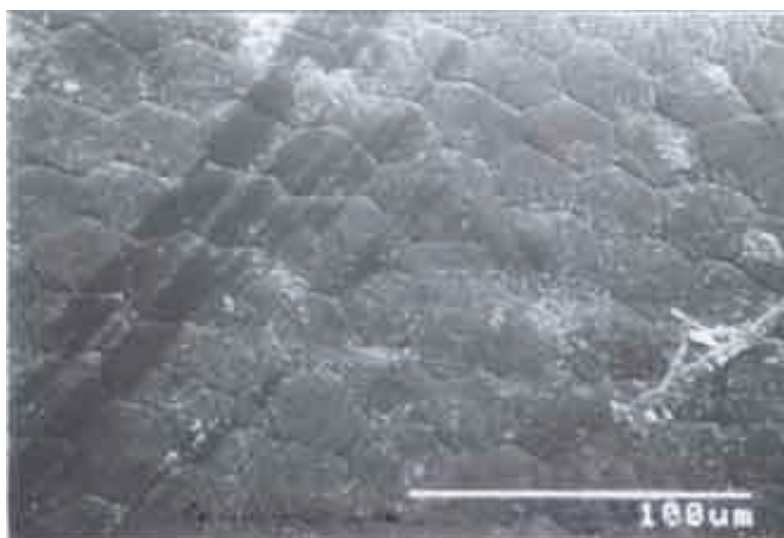

Fig. 3: scanning electron microscopy $(500 \mathrm{x})$. Details of the external cover of egg of Panstrongylus geniculatus originating laboratory colony. University of Antioquia, Colombia.

\section{RESULTS}

In the locality of La Gardenia, a total of 94 specimens of $P$. rufotuberculatus were found inside 3 rural houses: 2 eggs, 81 nymphs in all instars and adults of both sexes, 4 males and 6 females (Table I); besides, further evidence of intradomiciliary reproduction was found, such as 16 hatched eggs, exuviae and fragments of one dead insect. From these insects a laboratory colony was founded following Wolff and González (1998). At present, it has reached the third generation.

With respect to places of capture, $100 \%(\mathrm{~N}=94)$ of the insects were found indoors: in beds, $10.6 \%(\mathrm{n}=10)$; on walls, $6.38 \%(\mathrm{n}=6)$; under a wooden floor, $82.9 \%(\mathrm{n}=78)$.

The microscopic examination of faeces of 86 bugs showed 4 positive individuals as ( 2 fifth instar nymphs, 1 third instar nymph, and 1 female), giving a $4.6 \%$ rate of natural infection by $T$. cruzi.

Transmission risk indicators of T. cruzi - Table II shows the transmission risk indicators of $T$. cruzi by $P$. rufotuberculatus, for the locality of La Gardenia, according to the Indicator Definition Workshop for the Triatoma infestans Elimination Certification (OPS 1993).

\section{TABLE I}

Number of individuals, by instar, of Panstrongylus rufotuberculatus captured in La Gardenia, Amalfi, Colombia

\begin{tabular}{lcr}
\hline & Stages & No. \\
\hline Eggs & & 2 \\
Nymphs & I & 6 \\
& II & 9 \\
& III & 11 \\
& IV & 10 \\
& V & 15 \\
Adults & Between I and III instar & 15 \\
& Between I and V instar & 15 \\
& Males & 4 \\
Total & Females & 6 \\
& Incomplete body (head, thorax and wings) & 1 \\
\hline
\end{tabular}


TABLE II

Transmission Risk Indicators of Trypanosoma cruzi by Panstrongylus rufotuberculatus in La Gardenia, Antioquia, Colombia

Índicators La Gardenia

(P. rufotuberculatus)

Transmission Risk Index

Value

Density

(P. rufotuberculatus)

$\mathrm{N}^{\circ}$ of triatomines captured

$\mathrm{N}^{\circ}$ of residences of the locality

Domiciliary infestation

$=94 / 40$

(P. rufotuberculatus)

$\underline{\mathrm{N}^{\circ} \text { of residences with triatomines }} \times 100$

$\mathrm{N}^{\circ}$ of residences of the locality

$=2 / 40 * 100$

Colonization of houses

(P. rufotuberculatus)

$\mathrm{N}^{\circ}$ of residences with immature triatomines $\mathrm{x} 100$

$\mathrm{N}^{\circ}$ of residences with triatomines

Overcrowding

$=2 / 3 * 100$

(P. rufotuberculatus)

$\mathrm{N}^{\circ}$ of triatomines captured

$\mathrm{N}^{\circ}$ of residences with triatomines

$=94 / 3$

Natural infection by $T$. cruzi

$\mathrm{N}^{\circ}$ of positive triatomines $\mathrm{x} 100$

$\mathrm{N}^{\circ}$ of evaluated triatomines

$=4 / 86 * 100$

Relative infection by $T$. cruzi

$\mathrm{N}^{\circ}$ of residences with positive triatomines $\times 100$

$\mathrm{N}^{\circ}$ of evaluated residences

$=1 / 40 * 100$

\section{DISCUSSION}

For the first time, the domiciliary tendency of $P$. rufotuberculatus in Colombia was shown by finding 94 specimens inside two rural dwellings in a locality of La Gardenia, municipality of Amalfi, Antioquia. Findings included eggs, all nymphal instars, adults of both sexes and other evidences, such as hatched eggs, exuviae and fragments of dead insects. Transmission risk indicators of $T$. cruzi by P. rufotuberculatus in La Gardenia (Table II) show the capacity of adaptation shown by this sylvatic species and its potential success in domiciliation.

The dwellings in which immature instars were found are similar regarding construction and location: plastered walls, roofs of zinc sheets and ground floors; one of them was covered with boards, lacked electricity and was situated in a forest (near $80 \mathrm{~m}$ from the house) which had been altered by human activities such us agriculture and hunting. These conditions might have favoured the colonizing capacity of $P$. rufotuberculatus, since their prefered habitats are terrestrial, humid and dark.

All of the insects positive for $T$. cruzi, were found inside one rural house; 1 female and 3 nymphs of $3 \mathrm{rd}, 4$ th and 5 th instars. In that house were found adults forms (1 male and 1 female), 1 nymph 4th and 5 nymphs 5th, hatched eggs and some exuviae. The presence within dwellings of all stages of the life cycle of $P$. rufotuberculatus shows the capacity of this species to reproduce inside rural residences. This together with the $4.6 \%$ natural infection by $T$. cruzi shows that the human population of La Gardenia is suffering the epidemiological risk of getting Chagas disease.

The fact that it has been possible to colonize $P$. rufotuberculatus in our laboratory under stable conditions of temperature, humidity $\left(29^{\circ} \mathrm{C}, 90 \%\right)$ and luminos- ity, shows the reproductive capacity of this wild species in closed environments and its adaptability to environments with stable conditions, like those provided by the dwellings mentioned.

\section{REFERENCES}

Angulo VM, Gutiérrez R, Rubio I, Joya M, Arismendi M, Esteban L 1999. Triatomíneos domiciliados y silvestres: impacto en la transmisión de la enfermedad de Chagas en Santander. In VM Angulo, Control y Manejo de la Tripanosomiasis Americana, Gráficas Trijaimes, Bucaramanga, p. 72-76.

Arboleda J, Wolff M, Castillo D, Uribe J 2000. Prevalencia de anticuerpos contra Trypanosoma cruzi en reservorios domésticos y silvestres en Amalfi, Antioquia. Rev Col Cienc Pec 13: 11-18.

Barreto P, Barretto M 1984. Triatoma dispar (Hemiptera: Reduviidae) a new record for Colombia. J Med Entomol 21: 750.

Barreto P, Barretto M, Hurtado C 1988. Nuevos hallazgos de Colombia de Panstrongylus geniculatus (Latreille, 1811) y Triatoma dispar (Lent, 1950) (Hemiptera: Reduviidae). Colombia Med 19: 64-67.

Calderón GF, Figueroa Krap E, Naquira F 1985. Peru. In RU Carcavallo, JE Ravinovich, RJ Tonn (eds), Factores Biológicos y Ecológicos de la Enfermedad de Chagas, OPS/ ECO, MSAS/SNCh, Buenos Aires, p. 449-456.

Carvajal H, Caro FF, Bonelo A 1995. El Diagnóstico Directo en Parasitología, Centro Editorial Facultad de Salud, Universidad del Valle, $93 \mathrm{pp}$.

D’Alessandro A, Barreto P, Thomas M 1981. Nuevos registros de triatominos domiciliarios y extradomiciliarios en Colombia. Colombia Med 12: 75-85.

Dujardin JP, Forgues G, Torrez M, Martínez E, Córdoba C, Gianella A 1998. Morphometrics of domestic Panstrongylus rufotuberculatus in Bolivia. Ann Trop Med Parasitol 92: 219-228.

Espinal LF 1985. Revista Facultad Nacional de Agronomía, 
Geografía Ecológica del Departamento de Antioquia (Zonas de Vida Formaciones Vegetales) del Departamento de Antioquia, Medellín, 106 pp.

García Da Silva I, Ostermayer LuquettI A, García Da Silva HH 1993. Importancia do método de obtenção das dejeções dos triatomíneos na avaliação da susceptibilidade triatomínica para Trypanosoma cruzi. Rev Soc Bras Med Trop 26: 1924.

Lent H, Pifano F 1940. Sobre a identidade dos generos Panstrongylus Berg, 1879 e Mestor Kirkaldy, 1904. Redescrição de Panstrongylus rufotuberculatus encontrado na Venezuela naturalmente infetado pelo Schizotripanum cruzi. Rev Entomol 11: 629-639.

Lent H, Jurberg J 1969. Observaçoes sôbre o Ciclo Evolutivo, em laboratório, do Panstrongylys geniculatus (Latreille, 1811) (Hemiptera, Reduviidae, Triatominae). An Acad Brasil Cienc 41: 125-131.

Lent H, Wygodzinsky P 1979. Revision of the Triatominae (Hemiptera: Reduviidae), and their significance as vectors of Chagas Disease. Bull American Mus Nat Hist 163: 123520.

Marinkelle CJ 1972. Colombian Triatominae and their infestation with trypanosomatid flagellates. Mitt Inst ColomboAlemán Invest Cient 6: 13-29.

Miles MA, de Souza AA, Povoa M 1981. Chagas disease in the
Amazon basin. III. Ecotopes of ten triatomine bug species (Hemiptera: Reduviidae) from vicinity of Belem, Pará State, Brazil. J Med Entomol 18: 266-278.

Molina JA, Gualdrón LE, Brochero HL, Olano VA, Barrios D, Guhl F 2000. Distribución actual e importancia epidemiológica de las especies de triatominos (Reduviidae: Triatominae) en Colombia. Biomédica 20: 344-360.

Moreno J 1991. Recientes estudios epidemiológicos de tripanosomiasis americana en diferentes áreas de Colombia. Biomédica 11: 43-44.

OPS-Organización Panamericana de la Salud 1993. Taller de definición de indicadores para la certificación de la eliminación de Triatoma infestans. Rev Soc Bras Med Trop 26: 51-54.

Pinto N, Molina J, Zipa N, Cuervo R, Guhl F 1999. Determinación de la distribución de Triatominos en el Departamento de Boyacá. Resúmenes XXVI Congreso Soc Col Ent Socolen, p. 69.

Salomon O, Ripoll C, Rivetti E, Carcavallo R 1999. Presence of Panstrongylus rufotuberculatus (Champion, 1899) (Hemiptera: Triatominae) in Argentina. Mem Inst Oswaldo Cruz 94: 285-288.

Schofield CJ 1994. Triatominae. Biología y Control, Eurocommunica Publications, West Sussex, UK, 80 pp.

Wolff M, González C 1998. Ciclo de vida de Panstrongylus geniculatus (Hemiptera: Reduviidae) en condiciones de laboratorio. Caldasia 20: 75-77. 